\title{
Determinants for Effective Implementation of Electronic Payment System by Hospitals in Tanzania: A Case of the Kilimanjaro Christian Medical Centre
}

\author{
Kulwa Mang'ana \\ The Kilimanjaro Christian Medical Centre (KCMC), P. O. Box 3010, Moshi, Tanzania \\ E-mail: kulwa05@gmail.com
}

Mangasini Katundu (Corresponding author)

Senior lecturer at the Moshi Co-operative University (MoCU), P.O. Box 474, Moshi, Tanzania

E-mail: atanasi.mangasini@gmail.com

Received: Sep. 24, 2018 Accepted: Dec. 1, $2018 \quad$ Published: Dec. 21, 2018

doi:10.5296/bmh.v6i2.14083 URL: http://dx.doi.org/10.5296/bmh.v6i2.14083

\begin{abstract}
The era of rapid growth of the internet has witnessed the exponential growth of electronic payment systems (EPS); consequently, business transactions are constantly shifting from cash-based to electronic-based system. This paper is a product of a research conducted to explore factors that could influence effective adoption and implementation of the EPS among hospitals in Tanzania and the challenges associated with its adoption. The study used the KCMC as a case in point. The case study design was used. In this study we sampled 152 respondents randomly who included clients at the outpatient clinics of the hospital. The data were gathered using a structured questionnaire consistent with the Technology Acceptance Model (TAM). The findings suggest that the majority of the clients preferred to use EPS whereas, intention to use EPS, previous experience in the use of EPS, and being banked were significant factors influencing both preference of EPS and intention to use EPS. It is recommended that in order to hasten adoption of EPS in Tanzania it is important to address the identified barriers and also to encourage clients to keep their money in and use the services of banks.
\end{abstract}

Keywords: Electronic Payment Systems (EPS), TAM, Technology adoption, Hospitals, Tanzania 


\section{Introduction}

A payment system is significant for governance arrangements which encompass a set of relationships between the payment system management and its governing body (such as a board of directors), its owners and its other stakeholders. These arrangements provide the structure through which the system's overall objectives are set, how they are attained, and how performance is monitored. Because important payment systems have the potential to affect the wider financial and economic community, there is a particular need for effective, accountable and transparent governance, whether the system is owned and operated by the public or the private sector (Bassel, 2010). In the e-commerce world, almost invariably the customer does not actually see the concrete product at the time of transaction, and the method of payment is performed electronically (George, 2008). An effective payment system is not only for paying things or buying and selling stuff. It is important for keeping control and order, ensuring trade is legal and that tax is paid (Martina et al., 2003).

Most developed countries, including the USA, have recognized that billing systems are able to rapidly generate significant return on investment (ROI). This makes sense when we consider that the easiest way to increase revenue is to target the system directly responsible for billing and receiving revenue (Bruns et al., 2005). Billing systems can rapidly reduce processing expenses, improve cash flow, and increase customer satisfaction. A modern real-time billing system with electronic bill presentment and payment (EBPP) capability leads to a reduction in late payments and increases your cash on hand (Terplan, 2013).

For the hospitals in Tanzania the e-payment system was introduced to enable them to increase efficiency and revenue collection as staffs would have lesser time dealing with transaction processes. The system removes the hassle of carrying cash; it also cuts hospitals' administrative costs while serving liquidity leakage in the hospitals (Kimei, 2015). The main objectives of EPS are to increase efficiency, improve security, and enhance profitability of the hospital and customer convenience and ease of use (Bigdoli, 2002).

Technology has permitted electronic payments for medical treatment in a number of referral hospitals where a patient only needs a simple debited card. The Electronic Payment System (EPS), designed and offered by CRDB Bank PLC, allows patients to load their card using mobile money transfer for non-CRDB customers or Simbanking for the bank clients. The card is obtained by paying Tanzania Shillings (TZS) 2000 and credited money could be used at the Kilimanjaro Christian Medical Centre (KCMC) hospital, as indeed at other medical treatment centres like Bugando Medical Centre (BMC), Mbeya Referral Hospital, Arusha Lutheran Medical Centre, and Ilelembi Lutheran Medical Centre. The EPS at KCMC involves three main stakeholders: patients, the bank (CRDB) or agent of the bank where the patients need to process electronic cards and preload funds for the purpose of making hospital payments. The third is the Point of Sale (POS) centre where payments for medical services are cleared. The modes of payments in the hospital are irregular and are not made at par, that is, are made according to the stage of treatment. Clients are required to pay through CRDB and present the card to the cashier to clear payments. Many patients have a tendency to preload their cards with an amount of money equivalent to what is required at one stage and 
preload again at the next. Under these circumstances congestion may occur because one person would appear at one service centre more than once. In recent years Tanzania's hospitals, including $\mathrm{KCMC}$, have introduced automation features that allow client a flexible payment. A flexible billing system is necessary to stay competitive (Martina et al., 2015). To stay competitive, healthcare payers must be nimble enough to adopt their billing systems to health services and market segments, without incurring significant new Information Technology (IT) expenses. The payment system should give healthcare providers accountability for the types of services and costs that they can control, but not for services and costs over which the provider has little or no influence (Miller, 2012).

In February 2012, the CRDB Bank Plc launched electronic banking products where e-payment services were among other products that included Internet banking, Mobile banking, Sim banking, Tembocard, Automatic Teller Machine (ATM), POS, Money transfer and Shop on line services. On 18 March 2013 the hospital was contracted and enabled by the bank to access and use the EPS.

E-payment systems have been considered to be a crucial support service in the digital economy as they provide an efficient and reliable payment system (Durodolu, 2016). These payment systems enable faster payment, better tracking of transactions as well as transparency, which in turn reduces time, induces cost savings and promotes trusting relationships between buyers and sellers (Cheng, 2013). Introducing electronic system in an organization aims to increase efficiency and effectiveness. However, the opposite had been the case in using the system. Clients are still discouraged to use the electronic payment for medical treatment since they experience difficulties in getting services where network is weak or many patients wait long to make payments.

However, since its establishment at KCMC, very little is known on factors influencing the effective adoption and implementation of the electronic payment system by clients (patients). It is therefore the intention of this study to assess the factors influencing the electronic payment system by clients at the Kilimanjaro Christian Medical Centre in Moshi, Tanzania.

This study assessed the determinants for adoption and implementation of electronic payment system among clients at the Kilimanjaro Christian Medical Centre, Tanzania. Specifically the study:

Assessed the clients' preference between cash/paper based payment and EPS at KCMC;

1) Determined clients' intention to use EPS for hospital bill payments at KCMC;

2) Determined factors affecting intention to use EPS among clients of KCMC; and

3) Identified the obstacles to the adoption of electronic payment system among KCMC clients.

\section{Technology Acceptance Model and Electronic Payment System Adoption}

This study is based on the Technology Acceptance Model (TAM) propounded by Davis (1989) and advocated by Lai (2017). The TAM is an information systems theory that models how 
users come to accept and use a particular technology (Mugo et al., 2017; Momani \& Jamous, 2017). Park (2009) argues that TAM is considered an influential extension of theory of reasoned action (TRA), according to Ajzen and Fishbein (1980). The model suggests that when users are presented with a new technology that never existed before in their organization or community, a number of factors might influence their decision about how and when they will use it, notably: Perceived Usefulness (PU). This is defined as the degree to which a person believes that using a particular technology in place will enhance his or her job performance. Perceived Ease-of-Use (PEOU) defined as the degree to which a person believes that using a particular system would be free from effort (Davis, 1989). Figure 1 illustrates the Actual Use EPS as a product of external variables such as accessibility and/or the availability of the EPS itself. Other factors are perceived usefulness of the EPS, perceived ease-of-use, attitude toward using EPS and the behavioural intention to use EPS (Wong, 2017).

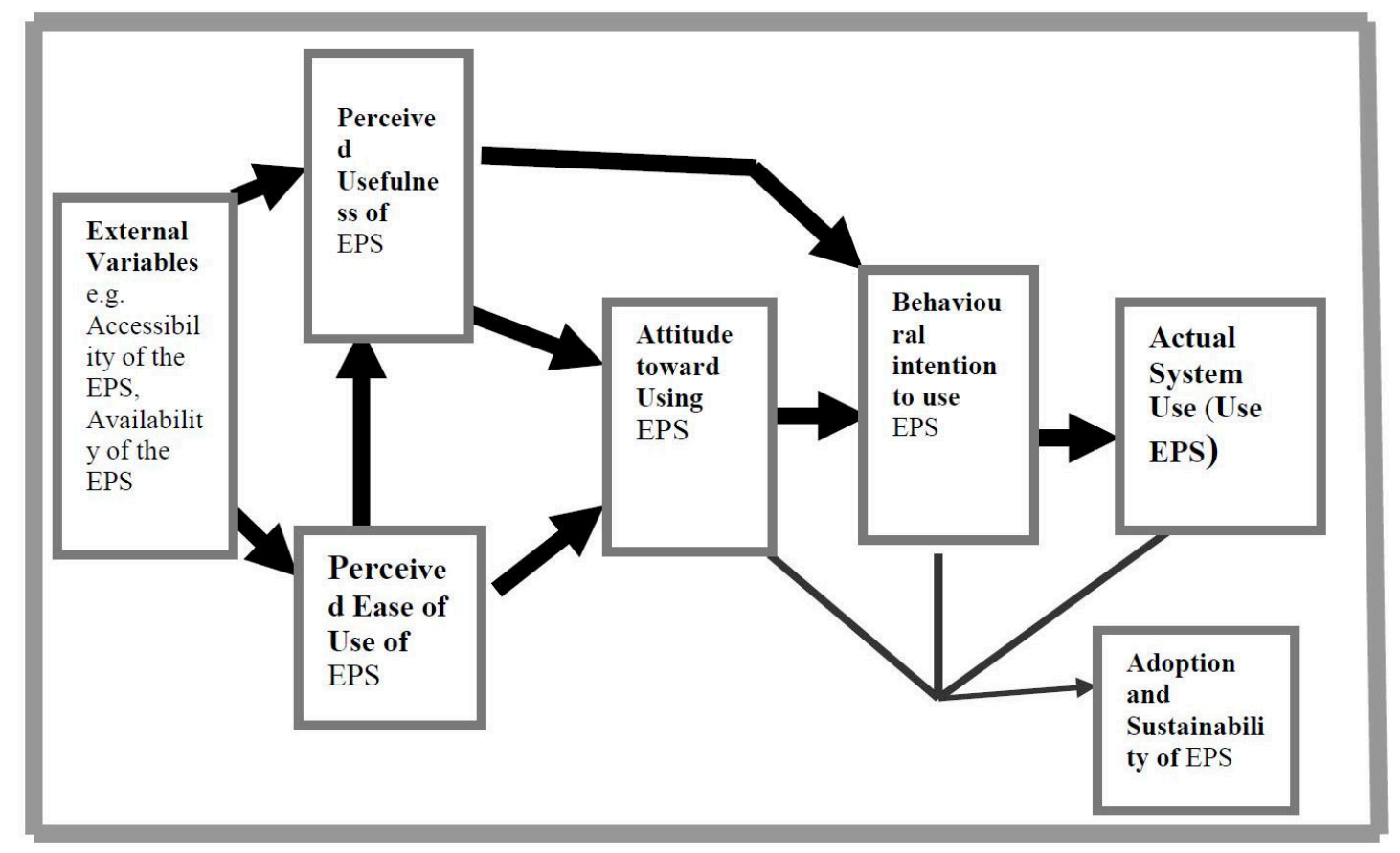

Figure 1. The technology acceptance model as modified from Davis (1989)

TAM provides a basis with which one traces how external variables influence belief, attitude, and intention to use. Two cognitive beliefs are posited by TAM: perceived usefulness and perceived ease of use. According to TAM, one's actual use of a technology system is influenced directly or indirectly by the user's behavioural intentions, attitude, perceived usefulness of the system, and perceived ease of the system (Folkinshteyn \& Lennon, 2016; Park 2009). TAM also proposes that external factors affect intention and actual use through mediated effects on perceived usefulness and perceived ease of use (Momani \& Jamous, 2017; Sargolzaei, 2017). He further argues that TAM appears to be able to account for more than 50 percent of user acceptance. Figure 2 shows how TAM behaves when other contextual 
variables are added.

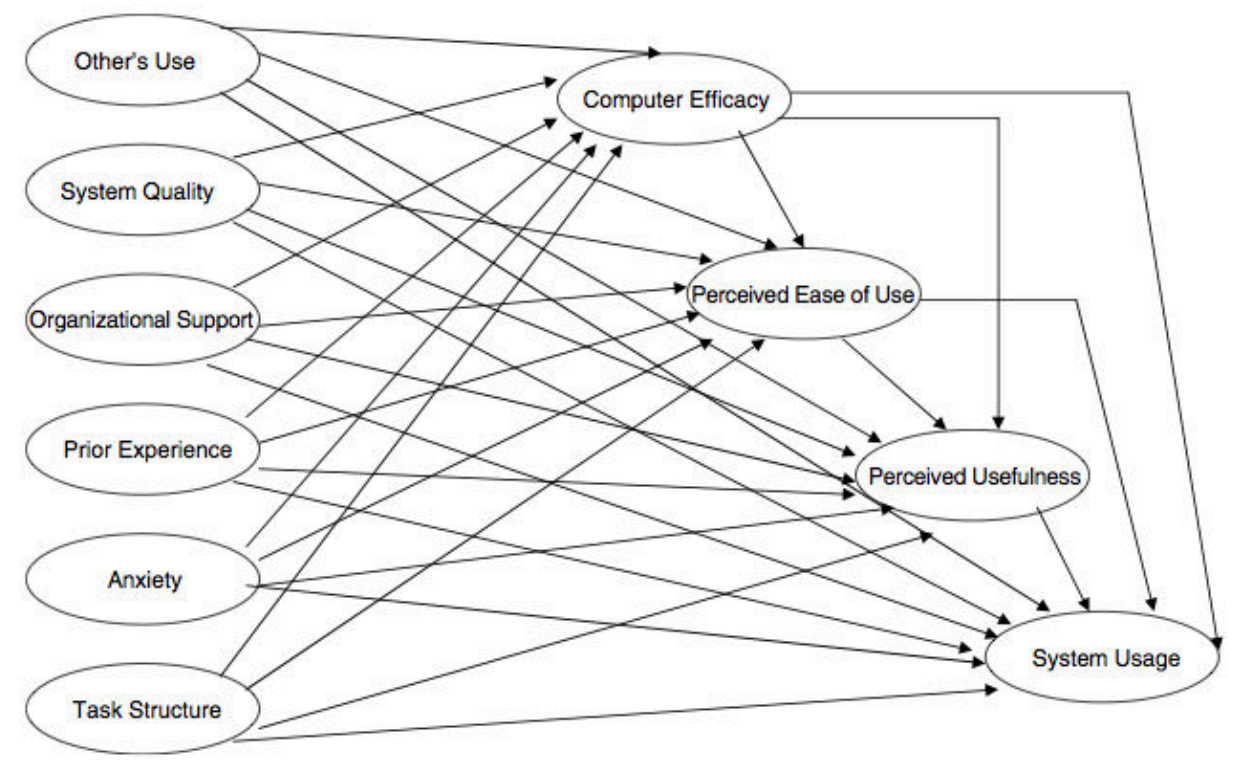

Figure 2. Adding contextual specificity to the Technology Acceptance Model from McFarland \& Hamilton (2006)

Several studies have examined TAM as a model to explain how people adopt and use various technologies such as e-learning (Selim, 2003; Lee et al., 2005; Liu et al., 2005; Pituch \& Lee, 2006; Beldad \& Hegner, 2017; Park, 2009; Chen et al., 2017) information technology (Dillon \& Morris, 1996; Oliveira \& Martins, 2011; Venkatesh et al., 2012), internet usage (Portera \& Donthu, 2006) and healthcare information systems (Paia \& Huang, 2011). Folkinshteyn and Lennon (2016) argue that TAM is an important analytical tool in the study of the social mechanisms of technology adoption, and this model has received considerable attention in the literature. Likewise, Schepers and Wetzels (2007) listed 53 studies using any one of six basic TAM constructs (attitude, intention of use, real use, subjective norms, perceived usefulness, perceived ease of use). Of these 53 studies, 15 of them found a significant relationship between perceived usefulness and attitude, varying from 0.29 to $0.84,15$ out of 16 discovered a significant relationship between perceived ease of use and attitude, varying from 0.05 to 0.73 , and 14 noted that there was a significant relationship between attitude and intention of use, varying from 0.11 to 0.75 . Sun and Zhan (2006) also studied the principal relations existing between the different basic constructs of the TAM. They retained a total of 72 studies all of which measured the perceived ease of use, 71 measured perceived usefulness, 22 measured attitude, 47 measured intention of use, while 39 measured real usefulness. They were thus able to confirm the existence of significant paths between attitude and intention of use as well as perceived usefulness: intention of use and real use, perceived usefulness and attitude as well as intention of use, and perceived ease of use and attitude as well as intention of use. Therefore, there is a need to understand the applicability of TAM on the sustainability of EPS. 


\section{Studies Related to Technology Adoption}

Various studies have been undertaken to study the adoption of new technologies both in developed and developing countries, though few studies on adoption of e-payments exist in developing countries, and specifically in the health sector. Tella (2012), using TAM to explain and predict the success of e-payment system among teaching and non-teaching academic staff at University of Ilorin in Nigeria, using One-way Analysis of Variance (ANOVA) and multiple regression/multiple correlation analysis, found that perceived ease of use, perceived enjoyment, speed, and service quality positively correlated with actual use of e-payments.

Dehbini et al. (2015) studied factors influencing the adoption of electronic payment cards in micro-payments among 384 citizens in Kuwait using most of TAM constructs. They tested hypotheses using one-sample t-test; effect of gender using Mann-Whitney $U$ test and other demographic variables using Kruskal-Wallis test. The results revealed that ease of use, perceived usefulness, network externalities and satisfaction had positive effect on acceptance of e-payments.

Another study by Wahid (2007) analyzing internet adoption between men and women in Indonesia using technology acceptance model found that perceived ease of use rather than perceived usefulness affected women than men while perceived usefulness was more important for men's adoption of internet.

A research by Anthony and Mutalemwa (2014) assessed factors influencing the use of Mobile Payment System in Tanzania. The study found that the rate of adoption of mobile payment services among the subscribers of Zantel (Z-Pesa) was grown in a relatively low rate, due to various factor that hinder adoption of service which include the perceived as being not so easy to use and unavailability of the service. The adoption of Z-Pesa services has the potential to be used as a means of payment if more payment options were available, such as paying utility bills, settling school fees and international money transfers.

Soboke (2015) in a descriptive study on factors influencing adoption of electronic payments by small and medium hotel enterprises in Kisii county, Kenya using Unified Theory of Acceptance and Use of Technology (UTAUT) model which is a modification of TAM, and using non-parametric tests (Kruskal Wallis mean rank test) concluded that background characteristics of users (education level, age, and skills) and ease of use in terms of speed and convenience highly influenced the adoption of e-payments.

Rumanyika (2015) assessing the obstacles towards Adoption of mobile banking in Tanzania noted that there are negative factors affecting mobile banking in the country. This research employed a quantitative approach in which descriptive analysis was adopted. The study revealed that poor network coverage, lack of knowledge of mobile banking users, lack of enough floats poor security of mobile network, are critical obstacles towards the adoption of mobile banking in Tanzania. The study recommends that the government and all other stakeholders should hastily focus their first priority to tackling the most critical obstacles

Nyamiaka (2015) in a study to determine the effects of e-payment on operational risk management in the private universities in Kenya using regression analysis, showed that 
electronic payment systems can be used in the private universities in Kenya to reduce misappropriation of funds by reducing 'ghost' payments, enhancing compliance with applicable accounting laws, reducing errors in calculating change from transactions, reducing fraudulent financial reporting and increasing transparency in transactions. The study also showed that institutions face infrastructural challenges due to lack of well-established infrastructure for acceptance of e-payments that are accessible, safe and easily operable by their clients.

Jansorn et al. (2013) investigating the determinants influencing the acceptance of electronic payment service in Thailand, revealed that if service is good, it will increase more acceptance of use. If most of the users (21-30) are to influence the E-payment vendors, the latter should be interested in such factors as would improve quality of services to attract more users.

Tella and Abdulmumin (2015) study examined users' satisfaction with the e-payment system at the University of Ilorin, Nigeria. Using a survey research approach the study revealed that Perceived speed was identified as the characteristics users were mostly satisfied with, followed by system security, traceability, and convenience. Moreover, there is significant correlation among the entire e-payment characteristics/factors (perceived speed, security, anonymity, traceability, perceived ease of payment, and convenience); and that all the six factors jointly predict users' satisfaction with the e-payment system.

Wendy et al. (2013) explored factors that influenced perception toward e-payment among Malaysian consumer using a self-administered questionnaire. Of the200 respondents 183 had valid responses. Upon linear regression analysis, three factors emerged as determinants of perception toward e- payment among consumers. These factors were benefits, self-efficacy and ease of use. However due to its small sample investigated, generalization of the results may be doubtful.

\section{Methodology}

A cross-sectional hospital-based study among clients attending out-patient departments (OPD) was undertaken. The study was designed as a cross section because it was done in a short period of time and for the descriptive purpose of the situation. The hospital is a huge complex with over 700 bed capacity; hundreds of patients came to the Center every day; over 1200 staff are employed there (KCMC annual Report, 2014). The study was ideal for study because the Centre has a well-established Local Area Network (LAN) and it was the only hospital that has recently introduced, in collaboration with the CRDB Plc, electronic payment for treatment in this region.

The population in Kilimanjaro region is mainly engaged in agricultural activities and, to some extent, animal husbandry. The main cash crop grown in the region is coffee. Food crops grown in the area include maize, beans, and bananas and, in some irrigated areas, rice. Most of the people in the area have education, mostly up to primary and secondary level.

The study population included all patients attending out-patient clinics and in-patients aged 18 years or older or persons accompanying them. These are the main beneficiaries of the EPS at the hospital. The sampling frame was patients (in- or out-patients) or accompanying 
relatives who were supposed to pay hospital bills for services received. The sampling unit was the patient or accompanying relative who was supposed to pay the hospital bill the sample size for this study was 152 respondents (Appendix A).

Systematic random sampling method was employed whereby every third patient attending outpatient clinic was invited to participate in the study. This allowed ample time to take the interview to a patient before the next one came and thus not delaying patients to get other services or to go home. The first patient to arrive at the medical records department was picked as the starting point.

Quantitative method of data collection was employed in this study. The data was collected by using the standardized questionnaire with structured questions adopted and adapted from TAM questionnaire (Davis, 1989; Abu-Dalbouh et al., 2017). The questionnaire consisted of socio-demographic characteristic of respondents of perceive ease of use, perceived usefulness, attitude towards using and behavioural intention to use. The questionnaire was written in English and translated into Swahili language, a language which was well understood by most of the people.

Data reliability and validity was carefully considered to facilitate the data obtained to provide firm support for the conclusion drawn from research. Cameron and Price (2009) consider the importance of telling good data from bad.

The research instrument was pre-tested with 20 patients who did not participate in the main study, to test its reliability using Cronbach's alpha. The value of the Cronbach's alpha above 0.80 is considered high reliability of the research instrument (Nunnally, 1978). Also, research assistants were trained before starting data collection with respect to questionnaire and questionnaire filling. The pilot study that was conducted involved the assistants to ensure that they were articulate with the questions.

Validity, on the other hand, is referred to as the accuracy of a result, that is, how well the designed tool measured what is supposed to be measured (Kothari, 2004). To ensure validity a standard TAM questionnaire was adopted (Davis, 1989) and questions adapted to fit the context in which the questionnaire was administered. Furthermore, a number of professionals in the subject including the supervisor were involved in checking the suitability and relevance of the questions.

The collected data was entered to the computer using Statistical Package for Social Sciences (SPSS) version 20). Model of estimation was done by using multivariate linear regression analysis for the purpose of testing hypotheses. Assumptions of linear regression analysis were performed using Kolmogorove-Smirnov test of Normality to test for normality of distribution of study variables and correlation analysis together with Variance Inflation Factor (VIF) to test for multicollinearity. Initially socio-demographic characteristics were assessed for significance test on intention to use e-payment systems. Mann-Whitney $U$ test was used to test for significance of ordinal variables. Adjusted $\mathrm{R}^{2}$ was used to assess variance explanation by the model and then each of the five constructs was tested for significant at 5\% level of significance. 


\section{Macrothink}

The study was conducted at only one institution with only a small sample and used only quantitative approach. This limits generalization of findings and hence replication of recommendations may be difficult to apply to other institutions and organizations. However, since this is a consultant health facility and clients come from all over the country, representativeness of the sample was mitigated.

The model used is a theoretical one measuring only intention to adopt the electronic payment systems. Since this model cannot capture the individual behavioural aspects that affect adoption, it can only be used to predict and not to realistically capture the actual factors that affect adoption of electronic payment systems.

\section{Findings and Discussion}

One hundred fifty two (152) clients attending at Kilimanjaro Christian Medical Centre $(\mathrm{KCMC})$ participated in the study. The majority were female $(59.3 \%, \mathrm{n}=89)$, aged between 20 and 40 years $(56.0 \%, n=89)$, and with post-secondary education $(59.3 \%, n=89)$. More than one-third were formal employees $(36.0 \%)$ and about half $(48.7 \%)$ had a monthly income ranging from Tanzania Shillings (TZS) 200000 to less than 600 000. Table 1 shows the results.

Table 1. Socio-demographic and economic characteristics of respondents $(n=150)$

\begin{tabular}{lll}
\hline Variable & Attribute & No. $(\%)$ \\
\hline Sex: & Male & \\
& Female & $61(40.7)$ \\
Age (years): & Less than 20 & $89(59.3)$ \\
& $20-30$ & $19(12.7)$ \\
& $31-40$ & $55(36.7)$ \\
& $41-50$ & $44(29.3)$ \\
& Older than 50 & $23(15.3)$ \\
& & $9(6.0)$ \\
Education level: & None & $11(7.3)$ \\
& Primary & $16(10.7)$ \\
& Secondary & $34(22.7)$ \\
& Above secondary & $89(59.3)$ \\
Occupation: & Farmer/peasant & $41(27.3)$ \\
& Employed & $54(36.0)$ \\
& Unemployed & $40(26.7)$ \\
& Business & $15(10.0)$ \\
& & \\
Month Income (TSHS) & Less than 200,000 & $43(28.7$ \\
& $200,000-<400,000$ & $27(18.0)$ \\
& $400,000-<600,000$ & $46(30.7)$ \\
& $600,000-<800,000$ & $23(15.3)$ \\
& 800,000 or above & $11(7.3)$ \\
\hline
\end{tabular}




\section{Macrothink}

Business and Management Horizons

ISSN 2326-0297

2018, Vol. 6, No. 2

Respondents were asked to indicate where they kept their money. The distribution of where respondents keep their money is shown in Figure 3. About one third of the respondents were keeping their money both in the bank and cell phone $(34.0 \%), 30.7 \%$ each in the bank/microfinance institution and in cell phone respectively.

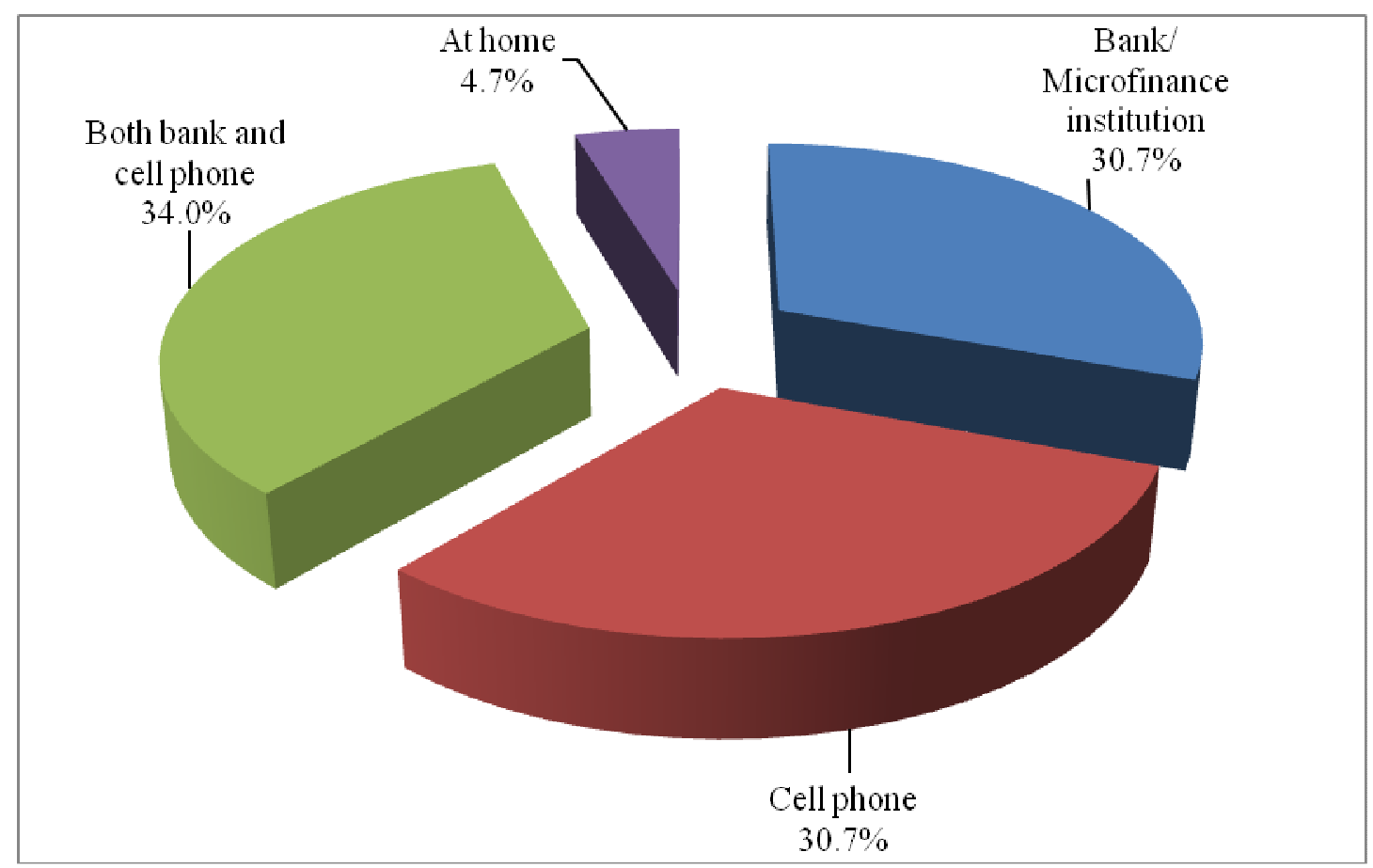

Figure 3. Institutions where respondents deposit their cash

5.1 Proportion of Clients Ever Used Electronic Payment System and Preferred Mode of Payment

Respondents were asked if they had paid hospital bills using electronic payment system (EPS). Out of 152 respondents, 64.7\% stated to have done so. These were further asked what mode of payment they prefer most. Out of 97 respondents, $58.8 \%$ preferred EPS, $33.0 \%$ both EPS and Cash whereas, only $8.2 \%$ preferred cash payment (Figure 4 ). The findings are not consistent with those reported in a study in Nigeria whereby more than three quarters of the respondents $(82.6 \%)$ preferred cash payments, giving the reason for not being used to the system (Nwaolisa \& Kasie, 2012). 


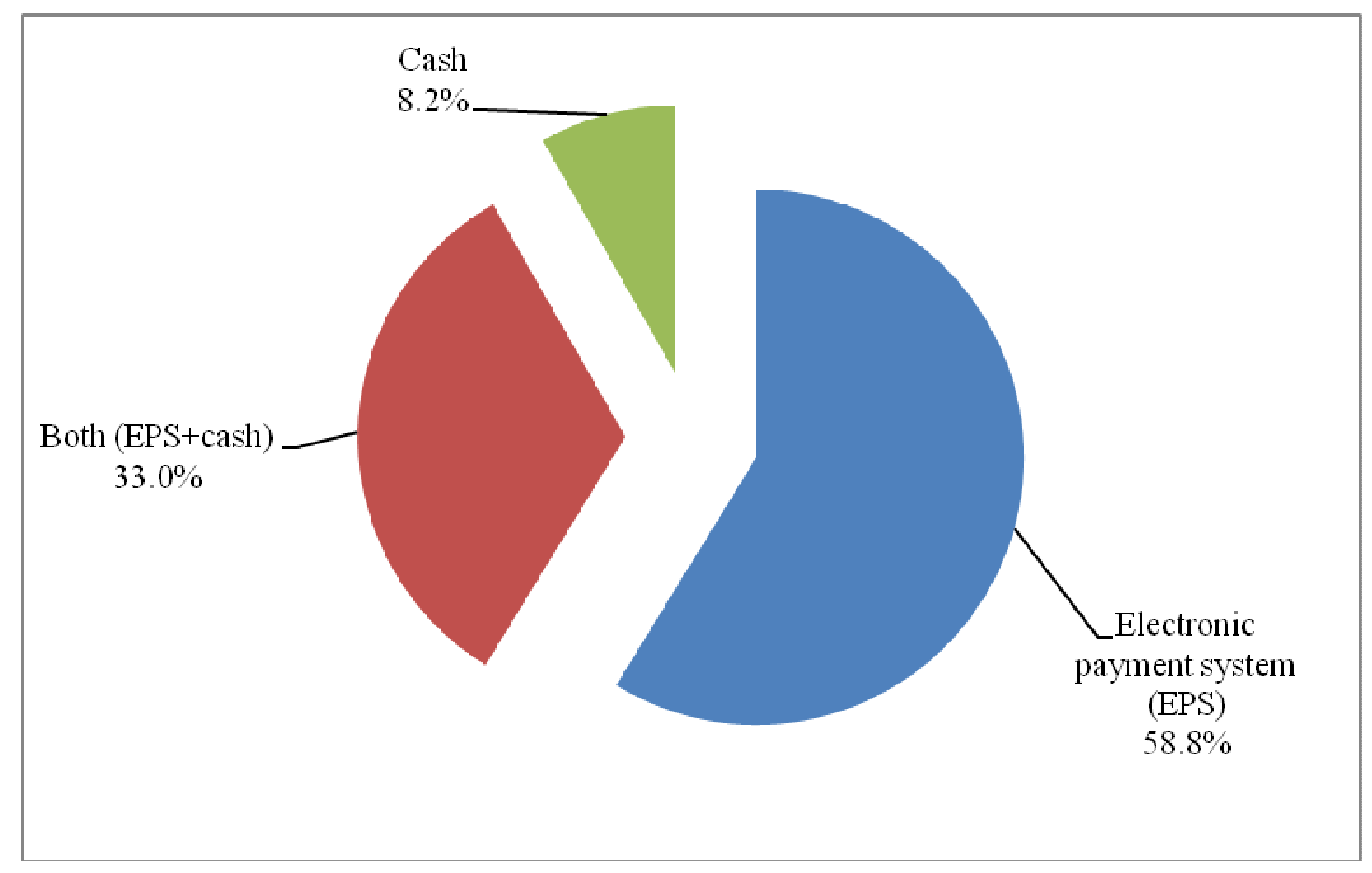

Figure 4. Most preferred mode of payment of hospital bills ( $n=97)$

\subsection{Socio-demographic and Economic Characteristics of Respondents}

Table 2 shows the relationship between socio-demographic and economic characteristics and preferred mode of payment of hospital bills. Clients who had previously made payments of hospital bills through electronic payment system were 6 times significantly more likely to prefer using the system than using cash payments (EPS) $(\mathrm{OR}=6.2,95 \% \mathrm{CI}=2.8-13.8$; $\mathrm{p}<0.001)$. Also, compared to clients keeping money in banks/microfinance institutions, clients keeping money in cell phones were 0.4 significantly less likely to prefer EPS than using cash payments $(\mathrm{OR}=0.4,95 \% \mathrm{CI}=0.1-1.0 ; \mathrm{p}=0.040)$ while those keeping their money at home were 0.2 times less likely to prefer EPS with no significant difference. Compared to farmers, employed and unemployed clients were 2.5 and 2.8 times respectively; significantly more likely to prefer EPS than cash payments $(\mathrm{OR}=2.5,95 \% \mathrm{CI}=1.0-6.1 ; \mathrm{p}=0.045$ and $\mathrm{OR}=2.8,95 \% \mathrm{CI}=1.0-7.6 ; \mathrm{p}=0.038$ respectively). Though male clients were about twice more likely to prefer EPS than female, the difference was not statistically significant. Likewise, compared to clients younger than 20 years, clients aged 41-50 years were about 8 times more likely to prefer EPS than cash payment but the difference was not significant. On the other hand, clients older than 50 years were 0.2 times less likely to prefer EPS with insignificant difference. Clients with higher than secondary education, business persons with monthly income higher than TZS 800,000 were more likely to prefer EPS than cash payments with no significant difference. (Hogarth et al., 2008) also attest that clients in the lower income bracket are less likely to prefer electronic payment systems.

Access to and utilization of banking services could explain the lower preference to electronic payment systems in favour of cash (Scholz \& Seshedri, 2009; Mann \& Mann, 2011). This 


\section{Macrothink}

could be the result of savings due to higher earnings (Johar \& Awalluddin, 2011; Lee, Lole, \& Tan, 2013), greater decision-making power at household level (men have more decision power in our patriarchal societies). This could explain why some clients are less likely to prefer to use electronic payment systems. A wide range of existing literature confirms that females compared to their male counterparts are either late majority or early majority, signifying that they take time to adapt to new technology including EPS (Wood \& Li, 2005; Hogarth et al., 2008; Liaw, 2002).

Literature suggests that old clients would be less likely than young ones to prefer using electronic payment systems (Hing, 2010; Hogarth et al., 2008; Lee, Lole, \& Tan, 2013); and most probably related to attitude towards risk and lack of experience or negative previous experience (Kim, 2012; Mann \& Mann, 2011; Aguiar \& Hurst, 2007).

Rogers (2003) argues that late majority and laggards (mostly older people according to Rose $\&$ Fogarty, 2010) are likely to be skeptical to innovations and adopt them when their use has been widely established and accepted. Thus, clients aged less than 20 years are mostly dependents and would in most cases not use banking services and hence less preference to EPS. Preference to electronic payment systems is further driven by previous use of the system which translates itself in the ease of use and usefulness. On the contrary, Johar and Awalluddin (2011) found that the age groups 51-60 years had higher tendency to adopt e-commerce. According to Nwaolisa and Kasie (2012) those who had previous experience were likely to prefer more than one electronic payment system signifying control over the systems and perceived convenience. Existing literature also suggests that female clients are reluctant to adopt new technologies due to risk aversion and awareness of how the system operates (Borghans et al., 2009; Sapienza et al., 2009; Hogarth et al., 2008; Hamza \& Shah, 2014). Furthermore, it has been shown that clients with higher education level adopt new technology faster than lower education level (Johar \& Awalluddin, 2011; Lee, Lole, \& Tan, 2013). In general, it has been alluded to the choice between electronic payments and cash is militated by socio-psychological factors such as emotions and habits (Bulletin, 2016). 


\section{Ml Macrothink}

Business and Management Horizons

ISSN 2326-0297

2018, Vol. 6, No. 2

Table 2. Association between socio-demographic and economic characteristics and preferred mode of payment

\begin{tabular}{|c|c|c|c|c|c|}
\hline \multirow[t]{3}{*}{ Variable (s) } & \multirow[t]{3}{*}{ Total } & \multicolumn{2}{|c|}{$\begin{array}{l}\text { Choice of mode of } \\
\text { payment }\end{array}$} & \multirow[t]{3}{*}{$95 \% \mathrm{CI}$} & \multirow[t]{3}{*}{ p-value } \\
\hline & & EPS & Cash & & \\
\hline & & No. (\%) & No. $(\%)$ & & \\
\hline \multicolumn{6}{|l|}{ Sex: } \\
\hline Male & 61 & $50(82.0)$ & $11(18.0)$ & & \\
\hline Female & 89 & $61(68.5)$ & $28(31.5)$ & $2.1(0.9-4.6)$ & 0.066 \\
\hline \multicolumn{6}{|l|}{ Age (years): } \\
\hline Younger than 20 & 19 & $14(73.7)$ & $5(26.3)$ & 1.0 & \\
\hline $20-30$ & 55 & $40(72.7)$ & $15(27.3)$ & $1.0(0.3-3.1)$ & 0.936 \\
\hline $31-40$ & 44 & $32(72.7)$ & $12(27.3)$ & $1.0(0.3-3.2)$ & 0.938 \\
\hline $41-50$ & 23 & $22(95.7)$ & $1(4.3)$ & $7.9(0.8-74.5)$ & $0.075^{*}$ \\
\hline Older than 50 & 9 & $3(33.3)$ & $6(66.7)$ & $0.2(0.0-1.0)$ & $0.095 *$ \\
\hline \multicolumn{6}{|l|}{ Level of education: } \\
\hline None & 11 & $8(72.7)$ & $3(27.3)$ & 1.0 & \\
\hline Primary & 16 & $6(37.5)$ & $10(62.5)$ & $0.2(0.0-1.2)$ & $0.120 *$ \\
\hline Secondary & 34 & $22(64.7)$ & $12(35.3)$ & $0.7(0.2-3.1)$ & $0.726^{*}$ \\
\hline Higher than secondary & 89 & $75(84.3)$ & $14(15.7)$ & $2.0(0.5-8.5)$ & $0.392 *$ \\
\hline \multicolumn{6}{|l|}{ Occupation: } \\
\hline Farmer & 41 & $24(58.5)$ & $17(41.5)$ & 1.0 & \\
\hline Employed & 54 & $42(77.8)$ & $12(22.2)$ & $2.5(1.0-6.1)$ & 0.045 \\
\hline Unemployed & 40 & $32(80.0)$ & $8(20.0)$ & $2.8(1.0-7.6)$ & 0.038 \\
\hline Business & 15 & $13(86.7)$ & $2(13.3)$ & $4.6(0.9-23.1)$ & $0.061 *$ \\
\hline \multicolumn{6}{|l|}{ Monthly income (TZS) } \\
\hline Less than 200,000 & 43 & $33(76.7)$ & $10(23.3)$ & 1.0 & \\
\hline $200,000-<400,000$ & 27 & $17(63.0)$ & $10(37.0)$ & $0.5(0.2-1.5)$ & 0.217 \\
\hline $400,000-<600,000$ & 46 & $35(76.1)$ & $11(23.9)$ & $1.0(0.4-2.6)$ & 0.942 \\
\hline $600,000-<800,000$ & 23 & $16(69.6)$ & $7(30.4)$ & $0.7(0.2-2.2)$ & 0.528 \\
\hline More than 800,000 & 11 & $10(90.9)$ & $1(9.1)$ & $3.0(0.3-26.6)$ & $0.426^{*}$ \\
\hline \multicolumn{6}{|l|}{ Place money is kept: } \\
\hline Bank/Microfinance institution & 46 & $37(80.4)$ & $9(19.6)$ & 1.0 & \\
\hline Cell phone & 46 & $28(60.9)$ & $18(39.1)$ & $0.4(0.1-1.0)$ & 0.040 \\
\hline Both (Bank + Cell phone $)$ & 51 & $43(84.3)$ & $8(15.7)$ & $1.3(0.5-3.7)$ & 0.618 \\
\hline At home & 7 & $3(42.9)$ & $4(57.1)$ & $0.2(0.0-1.0)$ & $0.053 *$ \\
\hline \multicolumn{6}{|c|}{ Ever made payment through EPS? } \\
\hline Yes & 97 & $84(86.6)$ & $13(13.4)$ & & \\
\hline No & 53 & $27(50.9)$ & $26(49.1)$ & $6.2(2.8-13.8)$ & $<0.001$ \\
\hline
\end{tabular}

Table 3 shows the relationship between socio-demographic and economic characteristics, perceived ease of use and perceived usefulness of electronic payment system. Perceived ease of use is significantly influenced by keeping money in the bank, having used EPS and preferring EPS as a method of payment of bills. On the other hand, perceived usefulness of EPS is significantly related to education higher than primary, having used EPS and preference of EPS over cash payments. In contrast to our study findings, other studies (Hamza \& Shah, 2014; Ong \& Lai, 2006; Wood \& Li, 2005) have demonstrated that the influence of perceived ease of use on mobile payment adoption significantly differed between male and female in favor of male students. On the other hand, Ong and Lai (2006) showed that perceived usefulness was significantly salient in men than female and determined men's behavioural 


\section{Macrothink}

Business and Management Horizons

ISSN 2326-0297

2018, Vol. 6, No. 2

intention to use new technology. Concurrent with the findings by Hogarth et al. (2008), our study found that higher level of education was associated with higher probability of perceived usefulness. Also, as Hogarth et al. (2008) attest, previous familiarity with EPS and preference of making payments through EPS are significantly associated with perceived ease of use and perceived usefulness of EPS

Table 3. Socio-economic characteristics of respondents

\begin{tabular}{|c|c|c|c|}
\hline \multirow{2}{*}{ Variable (s) } & \multirow{2}{*}{ Total } & PEOU & \multirow{2}{*}{$\begin{array}{l}\text { PU } \\
\text { Mean Rank }\end{array}$} \\
\hline & & Mean Rank & \\
\hline \multicolumn{4}{|l|}{ Sex: } \\
\hline Male & 61 & 83.7 & 80.5 \\
\hline Female & 89 & 69.9 & 72.1 \\
\hline \multicolumn{4}{|l|}{ Age (years): } \\
\hline Up to 40 & 118 & 75.1 & 76.3 \\
\hline Older than 40 & 32 & 77.0 & 72.5 \\
\hline \multicolumn{4}{|l|}{ Education level: } \\
\hline Up to primary & 27 & 62.5 & 59.1 \\
\hline Higher than primary & 123 & 78.4 & $79.1 *$ \\
\hline \multicolumn{4}{|l|}{ Occupation: } \\
\hline Formal employment & 54 & 68.3 & 68.1 \\
\hline No formal employment & 96 & 79.6 & 79.7 \\
\hline \multicolumn{4}{|l|}{ Monthly income (TZS): } \\
\hline Less than 400,000 & 70 & 76.9 & 77.9 \\
\hline 400,000 or more & 80 & 74.3 & 73.4 \\
\hline \multicolumn{4}{|l|}{ Where money is kept: } \\
\hline In bank & 97 & 81.0 & 79.3 \\
\hline Not in bank & 53 & $65.5^{*}$ & 68.6 \\
\hline \multicolumn{4}{|l|}{ Ever used EPS? } \\
\hline Yes & 97 & 85.6 & 82.4 \\
\hline No & 53 & $57.1 *$ & $62.9 *$ \\
\hline \multicolumn{4}{|c|}{ Preferred method of payment: } \\
\hline EPS & 111 & 84.9 & 84.0 \\
\hline Cash & 39 & $48.9 *$ & $51.3 *$ \\
\hline
\end{tabular}

EPS = Electronic Payment System; PEOU=Perceived ease of use of EPS; Perceived usefulness of EPS; $*=$ Significant at $\mathrm{p}<0.05$

\subsection{Clients'Intention to Use EPS}

Out of 150 respondents, about three quarters $(74.4 \%, \mathrm{n}=112)$ intended to use electronic payment systems. Socio-demographic and economic characteristics that significantly influence behavioural intention to use EPS included preference of using EPS and having experience with EPS. Clients who preferred using EPS for paying hospital bills over using cash were more than 4 times significantly likely to continue using EPS (OR=4.2, 95\% $\mathrm{CI}=1.9-9.1 ; \mathrm{p}<0.001)$ and clients with previous experience with EPS were about 8 times significantly likely to continue using EPS for paying bills than those without previous experience $(\mathrm{OR}=7.7,95 \% \mathrm{CI}=3.4-17.5 ; \mathrm{p}<0.001)$. Table 4 shows the results. 


\section{Macrothink}

Business and Management Horizons

ISSN 2326-0297

2018, Vol. 6, No. 2

Table 4. Relationship between socio-demographic and economic characteristics of clients and intention to use electronic payment systems

\begin{tabular}{|c|c|c|c|c|c|}
\hline \multirow[t]{2}{*}{ Variables } & \multirow[t]{2}{*}{ Total } & $\begin{array}{ll}\text { Intend } & \text { to } \\
\text { use EPS } & \\
\end{array}$ & $\begin{array}{l}\text { Do not intend to } \\
\text { use EPS }\end{array}$ & \multirow[t]{2}{*}{ OR $(95 \% \mathrm{CI})$} & \multirow[t]{2}{*}{ p-value } \\
\hline & & No. $(\%)$ & No. $(\%)$ & & \\
\hline \multicolumn{6}{|l|}{ Sex: } \\
\hline Male & 61 & $47(77.0)$ & $14(23.0)$ & & \\
\hline Female & 89 & $65(73.0)$ & $24(27.0)$ & $1.2(0.6-2.6)$ & 0.579 \\
\hline \multicolumn{6}{|l|}{ Age (years): } \\
\hline Up to 40 & 118 & $88(74.6)$ & $30(25.3)$ & & \\
\hline Older than 40 & 32 & $24(75.0)$ & $8(25.0)$ & $1.0(0.4-2.4)$ & 0.961 \\
\hline \multicolumn{6}{|l|}{ Education level: } \\
\hline Up to primary & 27 & $17(63.0)$ & $10(37.0)$ & & \\
\hline Higher than primary & 123 & $95(77.2)$ & $28(22.8)$ & $0.5(0.2-1.2)$ & 0.123 \\
\hline \multicolumn{6}{|l|}{ Occupation: } \\
\hline Formal employment & 54 & $42(77.8)$ & $12(22.2)$ & & \\
\hline No formal employment & 96 & $70(72.9)$ & $26(27.1)$ & $1.3(0.6-2.8)$ & 0.511 \\
\hline \multicolumn{6}{|l|}{ Monthly income (TZS): } \\
\hline Less than 400,000 & 70 & $54(77.1)$ & $16(22.9)$ & & \\
\hline 400,000 or more & 80 & $58(72.5)$ & $22(27.5)$ & $1.3(0.6-2.7)$ & 0.514 \\
\hline \multicolumn{6}{|l|}{ Where money is kept: } \\
\hline In bank & 97 & $76(78.4)$ & $21(21.6)$ & & \\
\hline Not in bank & 53 & $36(67.9)$ & $17(32.1)$ & $1.7(0.8-3.6)$ & 0.160 \\
\hline \multicolumn{6}{|l|}{ Ever used EPS? } \\
\hline Yes & 97 & $82(84.5)$ & $15(15.5)$ & & \\
\hline No & 53 & $30(56.6)$ & $23(43.4)$ & $4.2(1.9-9.1)$ & $<0.001$ \\
\hline \multicolumn{6}{|c|}{ Preferred method of payment: } \\
\hline EPS & 111 & $95(85.6)$ & $16(14.4)$ & & \\
\hline Cash & 39 & $17(43.6)$ & $22(56.4)$ & $7.7(3.4-17.5)$ & $<0.001$ \\
\hline
\end{tabular}

Internal consistency using Cronbach's alpha $(\alpha)$ exhibited high reliability of the study variables with $\alpha$ ranging between 0.83-0.94 ( $\alpha>0.80)$ (Table 5) which is considered high reliability (Nunally, 1978). Similar results were reported by Liu (2014) in a study on user acceptance and intention to use taxi-billing application in Shanghai, China using TAM whereby it $\alpha$ ranged between 0.82 and 0.89 for the study variables.

Pearson correlation coefficients were computed for the purpose of investigating the bivariate relationships (inter-correlation) among the study variables of perceived ease of use, perceived usefulness, attitude towards EPS and behavioural intention to use EPS. Table 5 shows the highest correlation coefficient ( $r$ ) is 0.796 (ranging from 0.610 to 0.796 ), that is, between attitude towards EPS and behavioural intention to use EPS. According to Field (2005), to avoid multicollinearity, the value of $r$ should be less than 0.8 and hence that problem is non-existent in our case. Variance Inflation Factor (VIF) test for multico-linearity was also performed and the values lied between 1 and 10 (range=1.9-2.1) indicating that there is no multicolinearity. Kolmogorov-Smirnov test did not exhibit any significance differences between the dependent variable and independent variables $(p>0.05)$ indicating that the normality assumption has been met (Table 5). 


\section{Mll Macrothink}

Business and Management Horizons

ISSN 2326-0297

Table 5. Pearson's correlation analysis, VIF, Cronbach's $\alpha$ and Kilmogorov-Smirnov tests of variables

\begin{tabular}{|c|c|c|c|c|c|c|c|}
\hline Variables & $\begin{array}{l}\text { Behavioural } \\
\text { intention to } \\
\text { use EPS }\end{array}$ & $\begin{array}{l}\text { Perceived } \\
\text { ease of use } \\
\text { of EPS }\end{array}$ & $\begin{array}{l}\text { Attitude } \\
\text { towards } \\
\text { EPS }\end{array}$ & $\begin{array}{l}\text { Perceived } \\
\text { usefulness of } \\
\text { EPS }\end{array}$ & $\begin{array}{l}\text { Mean } \\
(\mathrm{SD})\end{array}$ & VIF & $\begin{array}{l}\text { K-M } \\
\text { p-value }\end{array}$ \\
\hline $\begin{array}{l}\text { Behavioural intention } \\
\text { to use EPS }\end{array}$ & 1 & & & & $\begin{array}{l}3.9 \\
(0.9)\end{array}$ & & \\
\hline $\begin{array}{l}\text { Perceived ease of use } \\
\text { of EPS }\end{array}$ & $.659^{* *}$ & 1 & & & $\begin{array}{l}3.7 \\
(0.8)\end{array}$ & 1.9 & 0.07 \\
\hline Attitude towards EPS & $.796^{* *}$ & $.610^{* *}$ & 1 & & $\begin{array}{l}3.8 \\
(0.9)\end{array}$ & 2.0 & 0.12 \\
\hline $\begin{array}{l}\text { Perceived usefulness } \\
\text { of EPS } \\
\text { Instrument reliability: }\end{array}$ & $.610^{* *}$ & $.665^{* *}$ & $.645^{* *}$ & 1 & $\begin{array}{l}3.9 \\
(0.8)\end{array}$ & 2.1 & 0.32 \\
\hline Cronbach's alpha & 0.94 & 0.83 & 0.94 & 0.94 & & & \\
\hline
\end{tabular}

The findings show that attitude toward EPS was predicted by perceived ease of use of EPS $(\beta=0.610 ; p<0.001)$ and perceived ease of use of EPS $(\beta=0.645 ; p<0.001)$ and these two variables explain $47.5 \%$ of the variation $\left(\mathrm{R}^{2}=0.475\right)$ and hence $\mathrm{H} 1$ and $\mathrm{H} 2$ are supported. Behavioural intention to use EPS was predicted perceived usefulness $(\beta=0.645 ; \mathrm{p}<0.001)$ and attitude toward using EPS $(\beta=0.796 ; \mathrm{p}<0.001)$ and both explain $64.9 \%$ of the variation $\left(\mathrm{R}^{2}=0.649\right)$; hence $\mathrm{H} 3$ and $\mathrm{H} 4$ are supported. Perceived usefulness was predicted by perceived ease of use $(\beta=0.665 ; p<0.001)$ and explains $66.5 \%$ of the variation $\left(R^{2}=0.665\right)$. Figure 3 shows the results. Similar results were obtained in a study by Baraghani (2007) and Liu (2014) and hence consistent with prior research of the founder of TAM (Davis, 1989). Masrom (2007) contends that in order to instigate intention to use a new technology, positive perception on the technology's usefulness is a pre-requisite.

\subsection{Determinants of Behavioural Intention to Use Electronic Payment Systems}

Multivariate linear regression results revealed that the predictors of behavioural intention to use electronic payment systems were attitude toward EPS $(\beta=0.610 ; p<0.05)$ and ease of use of EPS ( $\beta=0.280 ; p<0.05)$. Usefulness of EPS was not a predictor of behavioural intention to use EPS (Table 5). The most significant prediction was mainly due to attitude toward EPS $(\beta=0.610)$ compared to ease of use of EPS $(\beta=0.280)$. Both variables explained $67.5 \%$ of the variation $\left(\mathrm{R}^{2}=0.675\right)$. The findings are consistent with those reported by Tella and Abdulmumin (2015) in Nigeria in a study on predictors of users' satisfaction with e-payment system among staff at the University of Ilorin; Tella and Olasina (2014) in their study of predicting users' continuance intention toward e-payment system; and Johar and Awalluddin (2011) on adoption of e-commerce. However, in all of these studies, perceived usefulness of EPS was also a predictor, in contrast to our study findings. Possible explanation to this could be the variables included in models and the outcome variable tested. Thus, Tella and Olasina used the extension of the TAM model and added variables such as enjoyment, speed, 


\section{Macrothink}

perceived benefits and user satisfaction on top of the three variables of the original TAM to predict actual use of EPS while Tella and Abdulmumin tested perceived security, convenience, speed, ease of payment, anonymity and traceability to predict user satisfaction and Johar and Awalluddin included perceived enjoyment in their technology acceptance model. Also Teoh, Chong and Chua (2013) using TAM to determine factors affecting consumers' perception of electronic payment in Malaysia found that ease of use, benefits and self-efficacy were the determinants of consumers' perception toward e-payment.

Table 6. Multivariate analysis results

\begin{tabular}{|c|c|c|c|c|c|}
\hline \multirow[t]{4}{*}{ Variable (s) } & \multirow[t]{4}{*}{$\beta$} & \multirow[t]{4}{*}{$\mathrm{T}$} & \multirow[t]{4}{*}{ p-value } & $95.0 \%$ & Confidence \\
\hline & & & & \multicolumn{2}{|c|}{ Interval for $\beta$} \\
\hline & & & & Lower & Upper \\
\hline & & & & Bound & Bound \\
\hline (Constant) & 1.690 & 1.532 & .128 & -.490 & 3.869 \\
\hline Attitude toward EPS & .610 & 9.471 & .000 & .482 & .737 \\
\hline Ease of use of EPS & .280 & 3.881 & .000 & .137 & .422 \\
\hline Perceived usefulness of EPS & .042 & .675 & .501 & -.080 & .163 \\
\hline Adjusted $\mathrm{R}^{2}$ & 0.675 & & & & \\
\hline
\end{tabular}

The final estimated model for intention to use EPS in our case would be:

$\mathrm{Y}_{\mathrm{i}}=1.690+0.610 \mathrm{X}_{1}+0.280 \mathrm{X}_{2}+0.042 \mathrm{X}_{3}+\varepsilon$

Where: $\mathrm{Y}_{\mathrm{i}}=$ Clients behavioural intention to use EPS

$\mathrm{X}_{1}=$ Attitude toward EPS

$\mathrm{X}_{2}=$ Perceived ease of use of EPS

$\mathrm{X}_{3}=$ Perceived usefulness of EPS

$\varepsilon=$ Random error

\subsection{Hypotheses Testing}

Based on the Technology Acceptance Model (TAM) adopted for the study, the following four hypotheses were tested to find out how they predict client's intention to use electronic payment systems and the results are presented in Table 7. 
Table 7. Hypotheses tested

\begin{tabular}{|c|c|c|}
\hline S/No. & Null Hypothesis (Ho) & Test Results \\
\hline & $\begin{array}{l}\text { Perceived ease of use (PEOU) do not influence client's } \\
\text { intention to use EPS }\end{array}$ & $\mathrm{p}<0.05$, Ho is rejected \\
\hline & $\begin{array}{l}\text { Perceived usefulness (PU) do not influence client's } \\
\text { behavioural intention to use EPS }\end{array}$ & $\mathrm{p}>0.05$, Ho is accepted \\
\hline & $\begin{array}{l}\text { Attitude toward electronic payment systems do not impact } \\
\text { client's behavioural intention to use EPS }\end{array}$ & $\mathrm{p}<0.05$, Ho is rejected \\
\hline & $\begin{array}{l}\text { Perceived ease of use do not impact client's intention to use } \\
\text { EPS }\end{array}$ & $\mathrm{p}<0.05$, Ho is rejected \\
\hline
\end{tabular}

\subsection{Challenges Facing EPS Implementation at KCMC}

The common barriers were downtime of Internet (mean $( \pm \mathrm{SD})$ score $=4.2( \pm 0.8))$ followed by poor Internet connectivity (mean $( \pm \mathrm{SD})$ score $=4.1( \pm 0.9)$ ) and then by power fluctuations (mean $( \pm \mathrm{SD})$ score $=4.0( \pm 0.9)$ ). The findings are consistent with those reported by Nwaolisa and Kasie (2011) who pointed out that the challenges facing electronic retail payment systems were weak technological infrastructures and inadequate power supply. Similar challenges have been reported by Issahaku (2012) in Ghana, Taddesse and Kidan (2005) in Ethiopia and Ngereza and Iravo (2013) in Kenya. Okifo and Igbunu (2015) in Nigeria also added issues concerning security of the e-payment system and resistance to change among clients. More findings see Figure 5.

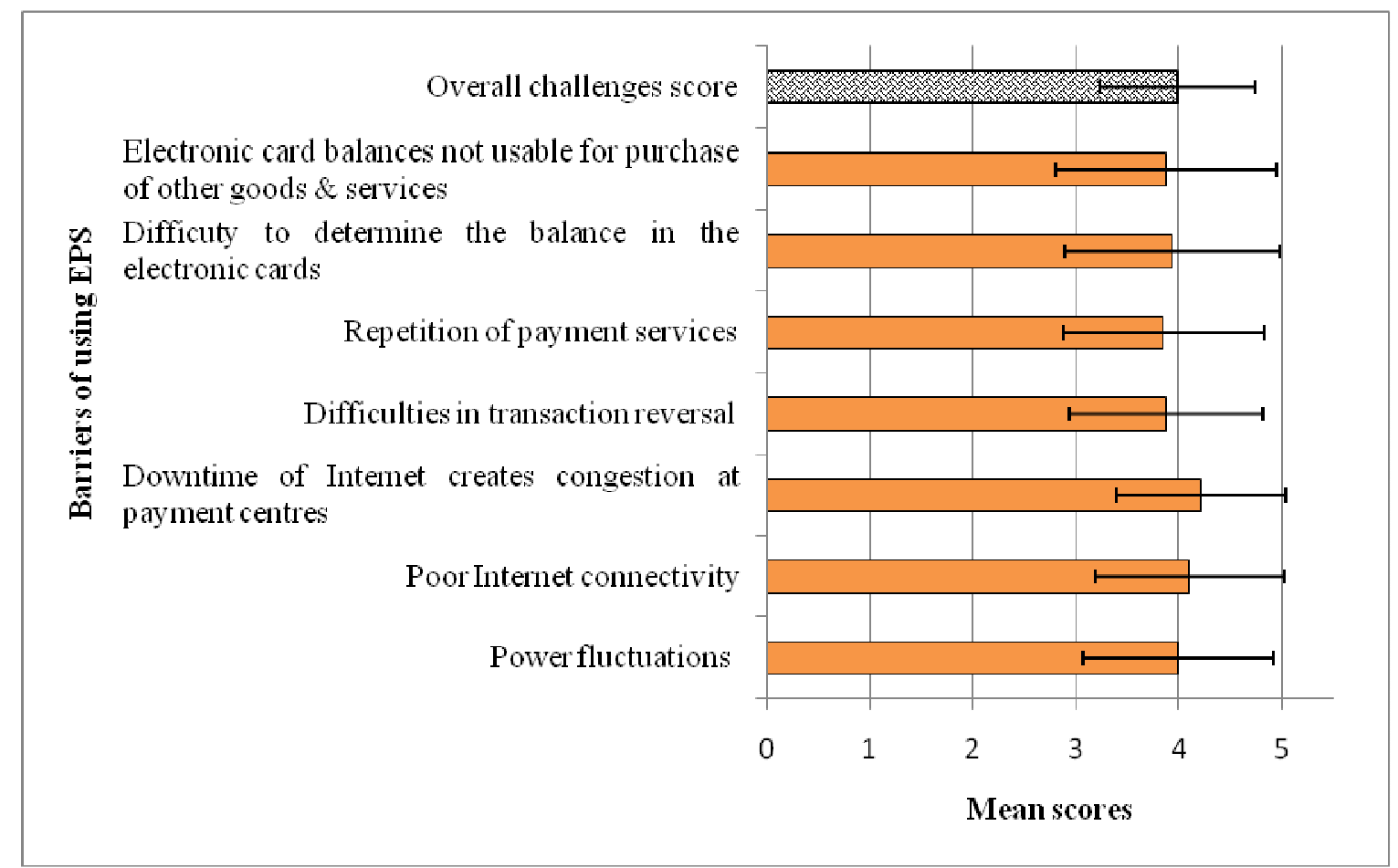

Figure 5. Barriers to using electronic payment systems 


\section{Summary, Conclusions and Recommendations}

In this sub-section we present the summary of key findings on the most preferred mode of payment by clients, attitude of clients toward the cash-base payments to electronic payments, factors influence clients to use e-payments at KCMC and challenges facing the adoption of the electronic payment system. We also present the conclusions and recommendations.

\subsection{Summary of Key Findings}

In assessing the determinants for adoption and implementation of electronic payment system among clients at the Kilimanjaro Christian Medical Centre, Tanzania, this study has that:

\subsubsection{The Most Preferred Mode of Payment by Clients}

The first objective of this study was to determine the mode of payment most preferred by the client at the hospital. Of those patients who had made payment previously, about two thirds prefer making payment using EPS than those who had never made any. One third prefers both cash and EPS. The indication is experience of using EPS attract the tendencies of continued use of EPS and signifying ability to control the system. Those clients with higher education adopt new technology more than those with lower education.

\subsubsection{The Attitude of Clients Toward the Cash-Base Payments to Electronic Payments}

The second objective was to determine the clients' intention to use EPS. Most of the respondent (nearly three quarter) showed intention to use EPS when they were asked the question assessing their intention to use EPS. The majority showed that the behavioural intention to use EPS include preference and experience of using EPS. Predictors of behavioural intention to use electronic payment systems were attitude toward EPS and ease of use of EPS.

\subsubsection{Factors Influence Clients to Use E-Payments at KCMC}

The third objective was to determine factors influencing clients' intention to use EPS. This study reviled that Perceive Ease of Use, Perceive Usefulness, Attitude towards EPS and behavioural intention to use EPS were the most factors influencing the clients to use EPS. Other factors include variables such as speed benefits and satisfaction.

\subsubsection{Challenges Facing the Adoption of the Electronic Payment System}

The final objective was to identify the challenges faced by the adoption of EPS. The most common barriers in EPS as reported by the respondents were downtime of Internet, Poor internet connectivity and Power fluctuation. Weak Technological infrastructure and inadequate power supply were also revealed as hindrance to the usage of EPS.

\subsection{Conclusions}

The majority of clients at KCMC prefer the electronic payment system to make payments for the health services. However, nearly one third of the clients still preferred both modes of payment, that is, cash and electronic payment systems. Significant factors influencing preference of mode of payment included being banked, previous experience of using EPS and 
being employed. The majority of clients intend to use electronic payment systems; factors that affect intention to use EPS are previous experience of using EPS and being banked.

All the five hypotheses of the TAM model were supported, demonstrating that perceived ease of use (PEOU) of EPS influenced perceived usefulness (PU) and both PEOU and PU influenced attitude toward EPS and also both PU and attitude toward EPS ultimately influenced behavioural intention to use EPS. Predictors of behavioural intention to use electronic payment systems were attitude toward EPS and ease of use of EPS.

The commonly mentioned challenges facing the adoption of electronic payment systems were downtime of Internet, followed by poor Internet connectivity and then by power fluctuations.

\subsection{Recommendations}

Since being banked was a significant factor affecting adoption of electronic payment systems, clients attending KCMC for services should be encouraged to bank their savings rather than saving their money using mobile telephone operators or keeping it at home. Furthermore, intention to use was influenced by previous experience which means that in order to enhance adoption of EPS, awareness creation on how the system works is crucial because this will enable clients to try and use the system and hence get accustomed to it.

Perceived usefulness was predicted by perceived use of electronic payment systems which was found to be higher among clients with primary education and above, it may be construed that awareness creation and education on how the electronic payments systems operate is important in order to foster adoption.

The barriers that were mentioned by clients, that is, downtime of Internet, poor Internet connectivity and power fluctuations must be addressed so as to reduce encumbrances that could deter clients from preferring the system.

However, the KCMC administration should look into the option of using both cash/paper based system and electronic payment system in case of power outage, therefore, there should be standby of receipt books; they should also install a reliable power back- up in all cash points to avoid waiting time when there is power outage. The administration in collaboration with the ICT unit should find a reliable network accessibility to avoid weak network during hours of service to the clients; concurrently, the KCMC administration should create patient awareness regarding the new system and increase the number of skilled personnel.

This study was carried out at a single institution and used only the quantitative approach. It is recommended that a larger multicentre study covering several institutions in different geographical locations and using both quantitative and qualitative approaches (triangulation of methods) are recommended for further area of study. Also, the model (TAM) used in this study has its pertinent weaknesses, especially for constructs capturing the individual feelings and beliefs that could influence intention to use a new technology. It is therefore recommended that studies using integrated models such as combining constructs from two or more models that also incorporate constructs capturing individual feelings and beliefs be carried out. 


\section{References}

Abu-Dalbouh, H. M., Al-Buhairy, M., \& Al-Motiry, I. (2017). Applied the Technology Acceptance Model in Designing a Questionnaire for Mobile Reminder. Computer and Information Science, 10(2), 15-24. https://doi.org/10.5539/cis.v10n2p15

Agarwal, R., \& Prasad, J. (1998). A conceptual and operational definition of personal innovativeness in the domain of information technology. Inf. Syst. Res., 9, 204-215. https://doi.org/10.1287/isre.9.2.204

Aguiar, M., \& Hurst, E. (2007). Life cycle prices and production. American Economic Review, 97(5), 1533. https://doi.org/10.1257/aer.97.5.1533

Ajzen, I., Fishben, M., \& Birjandi, H. (2015). Factors influencing adoption of electronic payment cards in urban micro-payments. Basic Research Journal of Business Management and Accounts, 4(2), 62-70.

Al Awadhi, S., \& Morris, A. (2009). Factors Influencing the Adoption of E-government Services. Journal of Software, 4(6), 585-590.

Al-adawi, Z., Yousafzai, Z., \& Pallister, J. (2005). Conceptual Model of Citizen Adoption of e-Government. International Conference on Innovations in Information Technology (IIT'05), Dubai.

Al-Qirim, N. (2007). The adoption and diffusion of e-commerce in developing countries: the case of an NGO in Jordan. Information Technology for Development, 13(2), 107-131. https://doi.org/10.1002/itdj.20053

Asokan, N., Janson, P., Steiner, M., \& Weidner, M. (2011). Electronic payment system. IBM Research Division, Zurich Research Laboratory.

Baddeley, M. (2004). Using e-cash in the new economy: an electronic analysis of micropayment systems. Journal of Electronic Commerce Research, 5(4), 239-253.

Bank of Tanzania. (2007). Electronic payment schemes guidelines.

Baraghani, N. (2007). Factors influencing the adoption of Internet banking. Dissertation for an award of master of Science degree at Lulea University of Technology: Lulea.

Beldad, A. D., \& Hegner, S. M. (2017). Expanding the Technology Acceptance Model with the Inclusion of Trust, Social Influence, and Health Valuation to Determine the Predictors of German Users' Willingness to Continue using a Fitness App: A Structural Equation Modeling Approach. International Journal of Human-Computer Interaction.

Boateng, K., Tetteh, I., \& Boateng, J. (2015). Managerial and usage challenges associated with the e-zwich payment system in Ghana. International Journal of Economics, Commerce and Management United Kingdom, III(2), 1-17.

Borghans, L., Bart, G., Heckman, J., \& Meijers, H. (2009). Gender differences in risk aversion and ambiguity aversion. UCD Geary Institute Discussion Pare Series. Rome. 
https://doi.org/10.3386/w14713

Burkhardt, M. (1994). Social interaction effects following a technological change: a longitudinal investigation. Academy of Management Journal, 37(4), 869-898.

Cameron, J., \& Price, D. (2000). Rewards, interest and performance: an evaluation of experimental findings. American Compensation Association Journal. Retrieved from http://zigonperf.com/PMNews/reward_and_per_research.html

Carter, L., \& Bélanger, F. (2005). The utilization of e-government services: citizen trust, innovation and acceptance factors. Information Systems Journal, 15(1), 2-25. https://doi.org/10.1111/j.1365-2575.2005.00183.x

Chau, P., \& Poon, S. (2003). Octopus: an e-cash payment system success story. Communication of the ACM, 46(9), 129-133. https://doi.org/10.1145/903893.903927

Chen, H., Rong, W., Ma, X., Qu, Y., \& Xiong, Z. (2017). An Extended Technology Acceptance Model for Mobile Social Gaming Service Popularity Analysis. Hindawi Mobile Information Systems, 1-12. https://doi.org/10.1155/2017/3906953

Colesca, S., \& Dobrica, L. (2008). Adoption and use of e-government services: Romania. $J$. Appl. Res. Technol., 6, 204-217.

Daniel, T. (2012). Automation of System Building. Boston: McGraw-Hill Irwin.

Davis, F. (1989). Perceived usefulness, perceived ease of use, and user acceptance of information technology. MIS Quarterly, 13(3), 319-340. https://doi.org/10.2307/249008

Dehbini, N., Birjandi, M., \& Birjandi, H. (2015). Factors influencing the adoption of electronic payment cards in urban micro-payments. Basic Research Journal of Business Management and Accounts, 4(2), 62-70.

Durodolu, O. O. (2016). Technology Acceptance Model as a predictor of using information system' to acquire information literacy skills. Retrieved from https://digitalcommons.unl.edu/cgi/viewcontent.cgi?article=4029\&context=libphilprac

Fielrd, A. (2005). Discovering statistics using SPSS (2nd ed.). London: SAGE.

Folkinshteyn, D., \& Lennon, M. (2016). Braving Bitcoin: A technology acceptance model (TAM) analysis. Journal of Information Technology Case and Application Research, 18(4), 220-249. https://doi.org/10.1080/15228053.2016.1275242

Hamza, A., \& Shah, A. (2014). Gender and Mobile Payment System Adoption among Students of Tertiary Institutions in Nigeria. International Journal of Computer and Information Technology, 3(1), 13-20.

Hassan, I., Schmiedel, H., \& Song, L. (2012). Returns to retail banking and payments. Journal of Financial Services Research, 41(3), 163-195. https://doi.org/10.1007/s10693-011-0114-y

Hing, A. (2010). Why are elderly reluctant to adopt new payment technologies. Lydian 
Journal, 2(34), 34-56.

Hogarth, J., Kolodinsky, J., \& Gabor, T. (2008). Consumer Payment Choices: Paper, Plastics or Electrons. International Journal of Electronic Banking, 1(1). https://doi.org/10.1504/IJEBANK.2008.020437

Jaeger, P., \& Matteson, M. (2009). E-government and technology acceptance: The case of the implementation of section 508 guidelines for websites. Electron. J. e-Gov., 7(23), 87-98.

Johar, G., \& Awalluddin, J. (2011). The role of technology acceptance model in explaining effect of e-commerce application system. International Journal of Managing Information Technology, 3(3), 1-14. https://doi.org/10.5121/ijmit.2011.3301

Kabir, M. A., Saidin, S. Z., \& Ahmi, A. (2015). Adoption of E-Payment Systems: A Review of Literature, in Malaysia.

Kim, K. (2012). The emotional responses of older adults to new technology. Dissertation for the degree of Doctor of Philosophy in Kinesiology at the University of Illinois.

Lai, P. C. (2017). The Literature Review of Technology Adoption Models and Theories for the Novelty Technology. Journal of Information Systems and Technology Management, 14(1), 21-38. https://doi.org/10.4301/S1807-17752017000100002

Lee, H., Loke, Y., \& Tan, K. (2013). The demand for e-payments in Malaysia: an examination of usage intensity. The Journal of Applied Economic Research, 7(4), 371-389. https://doi.org/10.1177/0973801013500167

Leong, E., Leong, K., Ewing, M., \& Pitt, F. (2003). Australian marketing managers' perceptions of the internet: a quasi-longitudinal perspective. European Journal of Marketing; 39(4), 34-67. https://doi.org/10.1108/03090560310459087

Liaw, S. (2002). An Internet survey for perceptions of computers and the World Wide Web: relationship, prediction and difference. Computers in Human Behavior, 18(1), 17-35. https://doi.org/10.1016/S0747-5632(01)00032-2

Lynch, D., \& Lundquist, L. (1996). Digital money: the new era of Internet commerce. Chichester: Wiley. Retrieved from rtooe.504pionn/peoe/lo.cd10i

Mann, A., \& Mann, R. (2011). Debt, financial distress and bankruptcy over the life course. Mimeo.

McClure, D. (2001). Electronic government: challenges must be addressed with effective leadership and management.

Mcfarland, D., \& Hamilton, D. (2006). Adding contextual specificity to the technology acceptance model. Computers in Human Behavior, 22(3), 427-447. https://doi.org/10.1016/j.chb.2004.09.009

McKnight, H., Choudhury, V., \& Kacmar, C. (2002). Developing and validating trust measures for e-commerce: an integrative typology. Information Systems Research, 13, 
334-359. https://doi.org/10.1287/isre.13.3.334.81

Medivinsky, G., \& Neuman, B. (1995). Requirements for network payment: the netcheque perspective. Proceedings of the IEEE Compcon 9523 May 2014, San Francisco.

Momani, A. M., \& Jamous, M. M. (2017). The Evolution of Technology Acceptance Theories. International Journal of Contemporary Computer Research, 1(1), 51-58.

Mugo, D. G., Njagi, K., Chemwei, B., \& Motanya, J. O. (2017). The Technology Acceptance Model (TAM) and its Application to the Utilization of Mobile Learning Technologies. British Journal of Mathematics \& Computer Science, 20(4), 1-8. https://doi.org/10.9734/BJMCS/2017/29015

Ngereza, K., \& Iravo, M. (2013). Challenges influencing implementation of electronic payment systems: a case study of Kenya Airways Company. International Journal of Social Sciences and Entrepreneurship, 1(3), 509-520.

Nunnally, J. (1978). Psychometric theory (2nd ed.). New York: McGraw-Hill.

Nwaolisa, F., \& Kasie, G. (2012). Electronic retail payment systems: user acceptability and payment problems in Nigeria. Arabian Journal of Business and Management Review (OMAN Chapter), 1(6), 18-35. https://doi.org/10.12816/0002106

Nyamiaka, S. (2015). Effects of E-Payment on Operational Risk Management. Dissertation for an award of MBA at International University Africa, United States.

O’brien, J., \& Marakas, G. (2006). Management Information Systems (7th ed.). New York: McGraw-Hill Companies.

Okifo, J, \& Igbunu, R. (2015). Electronic payment systems in Nigeria: its economic benefits and challenges. Journal of Education and Practice, 6(16), 56-62.

Ong, C., \& Lai, J. (2006). Gender differences in perceptions and relationships among dominants of e-learning acceptance. Computers in Human Behaviour, 22(5), 816-829. https://doi.org/10.1016/j.chb.2004.03.006

Özkan, S., Bindusara, G., \& Hackney, R. (2010). Facilitating the adoption of e-payment systems: theoretical constructs and empirical analysis. Journal of Enterprise Information Management, 23(3), 305-325. https://doi.org/10.1108/17410391011036085

Plouffe, R., Hulland, S., \& Vandenbosch, M. (2001). Richness versus parsimony in modeling technology adoption decisions - understanding merchant adoption of a smart card-based payment system. Information Systems Research, 12(2), 208-222. https://doi.org/10.1287/isre.12.2.208.9697

Rice, R., \& Adyin, C. (2004). Attitudes towards new organizational technology: network proximity as a mechanism for social information processing. Administrative Science Quarterly, 36(2), 219-244. https://doi.org/10.2307/2393354

Robert, T. (2013). KCMC annual report, for Financial end of the year. Moshi, Tanzania. 
Rogers, E. (1995). Diffusion of Innovations. New York, USA: The Free Press.

Rogers, E. (2003). Elements of diffusion. Diffusion of Innovations, 5, 1-38.

Rose, J., \& Fogarty, G. (2010). Technology readiness and segmentation profile of mature consumers.

Rumanyika, D. (2015). Obstacles Towards Adoption Of Mobile Banking In Tanzania: A Review. International Journal of Information Technology and Business Management, 35(1), $1-17$.

Sang, S., Lee, J., \& Rino, J. (2009). E-government adoption in ASEAN: the case of Cambodia. Internet Res., 19, 517-534. https://doi.org/10.1108/10662240910998869

Sapienza, P., Zingales, L., \& Maestripieri, D. (2009). Gender differences in financial risk aversion and career choices are affected $\mathrm{b}$ testosterone. Proceedings of the National Academy of Sciences, 106(36), 15268-15273. https://doi.org/10.1073/pnas.0907352106

Sargolzaei, S. (2017). Developing technology acceptance models for decision making in urban management. MOJ Civil Engineering, 2(6), 180-182.

Schoenmaker, B. (1998). Basic security of the e-cash payment system, Computer security and industrial cryptography: state of the art and evolution. Springer-Verlag.

Scholz, J., \& Seshedri, A. (2009). The assets and liabilities held by low-income families. In R. M. Blank \& M. S. Barr (Eds.), Insufficient funds: savings, assets, credit and banking among low-income households (p. 230). New York, Russell Sage.

Shon, T., \& Swatman, P. (1998). Identifying effectiveness criteria for internet payment system. Internet Research: Electronic Networking Applications and policy, 8(3), 202-218. https://doi.org/10.1108/10662249810217759

Soboke, E. (2015). Factors influencing adoption of electronic payment by small and medium hotel enterprises in Kisii county, Kenya. International Journal of Novel Research in Computer Science and Software Engineering, 2(2), 5-18.

Taddesse, W., \& Kidan, T. (2005). e-payment: challenges and opportunities, United Nations, Economic Commission for Africa report. Ethiopia.

Taddesse, W., \& Kidan, T. (2010). E-payment: challenges and opportunities in Ethiopia. Journal of Internet Banking \& Commerce, 12(2), 34.

Tella, A. (2012). Determinants of e-payment systems success: A user satisfaction perspective. International Journal of E-adoption, 4(3), 15-38. https://doi.org/10.4018/jea.2012070102

Teoh, W., Chong, S., \& Chua, J. (2013). Factors affecting consumers' perception of electronic payment: an empirical analysis. Internet Research, 23(4), 465-485. https://doi.org/10.1108/IntR-09-2012-0199

Truma, G., Sandoe, K., \& Rifkin, T. (2003). An empirical Study of smart card technology. Information and Management, 6(40), 591-606. 
https://doi.org/10.1016/S0378-7206(02)00046-0

Wahid, F. (2007). Using the technology adoption to analyze Internet adoption and use among men and women in Indonesia. Electronic Journal of Information Systems in Developing Countries, 32(6), 1-8. https://doi.org/10.1002/j.1681-4835.2007.tb00225.x

Wangpipatwong, S., Chutimaskul, W., \& Papasratorn, B. (2008). Understanding citizen's continuance intention to use e-Government website: a composite view of technology acceptance model and computer self-efficacy. The Electronic Journal of e-Government, 6(1), 55-64.

Whinston, A., \& Zhang, H. (1999). Building trust in the electronic market through an electronic incentive mechanism. International Conference on Information Systems, North Carolina, United States.

Wong, S. H. (2017). Using the Technology Acceptance Model in Understanding Staff Acceptance and Attitudes to Use Lecture Capture System. Proceedings of 59th IASTEM International Conference, Hong Kong, 27th-28th June 2017

Wood, W., \& Li, S. (2005). The empirical analysis of technology camel. Issues of Information System, 6(2), 154-160.

Worku, G. (2010). Electronic banking in Ethiopia-practices, opportunities and challenges. Journal of Internet Banking \& Commerce, 12(2), 45-50.

\section{Appendix A}

\section{Sample Size Determination}

The required sample size was derived from the following formula (Cochran, 1977)

$$
\mathrm{n}=\underline{\mathrm{Z}^{2} \mathrm{P}(1-\mathrm{P})}
$$

$$
\mathrm{d}^{2}
$$

Where:

$\mathrm{n}=$ minimum sample size

$\mathrm{Z}=$ standard normal deviation (1.95 for $95 \%$ confidence interval)

$\mathrm{P}=$ proportional of respondents showing negative attitude towards adoption of EPS 90\% obtained in study done in Zimbabwe (Daniel, 2012)

$\mathrm{d}^{2}=$ Marginal error which is $5 \%$

Thus, the minimum sample size was found to be:

$$
\mathrm{n}=\frac{3.84 * 90 \%(100-90 \%)}{5 \%^{2}}=138
$$

Assuming 10\% non-response rate/refusals, the minimum sample size was taken to be 152 . 


\section{Macrothink}

\section{Copyrights}

Copyright for this article is retained by the author(s), with first publication rights granted to the journal.

This is an open-access article distributed under the terms and conditions of the Creative Commons Attribution license (http://creativecommons.org/licenses/by/4.0/). 